\title{
Affordability and Availability of Child Restraints in an Under-Served Population in South Africa
}

\author{
Prasanthi Puvanachandra 1,2,*, Aliasgher Janmohammed ${ }^{3}$, Pumla Mtambeka ${ }^{3}$, Megan Prinsloo ${ }^{4}$, \\ Sebastian Van As ${ }^{5}$ and Margaret M. Peden ${ }^{1,2}$ (C) \\ 1 The George Institute for Global Health UK, Oxford University, Oxford OX1 2BQ, UK; \\ margie.peden@georgeinstitute.ox.ac.uk \\ 2 School of Public Health and Community Medicine, University of New South Wales, Sydney 2052, Australia \\ 3 ChildSafe South Africa, Woolworths ChildSafe Research and Educational Centre, Red Cross Children's \\ Hospital, Cape Town 7701, South Africa; Ali@childsafe.org.za (A.J.); Pumla@childsafe.org.za (P.M.) \\ 4 Burden of Disease Research Unit, South African Medical Research Hospital, Tygerberg 7505, South Africa; \\ Megan.Prinsloo@mrc.ac.za \\ 5 Red Cross Children's Hospital, University of Cape Town, Cape Town 7701, South Africa; \\ sebastian.vanas@uct.ac.za \\ * Correspondence: Prasanthi.attwood@georgeinstitute.ox.ac.uk
}

Received: 19 February 2020; Accepted: 14 March 2020; Published: 17 March 2020

check for updates

\begin{abstract}
Background: Child road traffic injuries are a major global public health problem and the issue is particularly burdensome in middle-income countries such as South Africa where injury death rates are 41 per 100,000 for under 5's and 24.5 per 100,000 for 5-14-year-old. Despite their known effectiveness in reducing injuries amongst children, the rates of use of child restraint systems (CRS) remains low in South Africa. Little is known about barriers to child restraint use especially in low- and middle-income countries. Methods: We carried out observation studies and parent/carer surveys in 7 suburbs of Cape Town over a three month period to assess usage rates and explore the knowledge and perceptions of parents towards child restraint legislation, ownership and cost; Results: Only $7.8 \%$ of child passengers were observed to be properly restrained in a CRS with driver seatbelt use and single child occupancy being associated with higher child restraint use. 92\% of survey respondents claimed to have knowledge of current child restraint legislation, however, only $32 \%$ of those parents/carers were able to correctly identify the age requirements and penalty. Reasons given for not owning a child seat included high cost and the belief that seatbelts were a suitable alternative. Conclusions: These findings indicate the need for a tighter legislation with an increased fine paired with enhanced enforcement of both adult seatbelt and child restraint use. The provision of low-cost/subsidised CRS or borrowing schemes and targeted social marketing through online fora, well baby clinics, early learning centres would be beneficial in increasing ownership and use of CRS.
\end{abstract}

Keywords: child injury; passengers; restraints; affordability; availability

\section{Introduction}

Globally, 21\% of road traffic deaths occur among children aged 0-19 year [1]. Road traffic injuries (RTIs) are the leading cause of death amongst children aged 1-19 years with global rates being estimated at 10.7 per 100,000 population [2,3] Of these, $93 \%$ occur in low- and middle-income countries (LMIC) such as South Africa (SA) where the overall (all age) road traffic fatality rate is estimated to be 33.2 per 100,000 population. Children are especially vulnerable road users in SA, with road traffic crashes being the second leading cause of death for children aged 5-14 years [4]. There is a growing concern for those children being transported in vehicles as vehicle ownership increases and there is a greater reliance on public service vehicles [5,6]. 
The World Health Organization (WHO) has declared that the main risk factor for young children being injured as a result of a road traffic collision is the lack of or improper use of an appropriate restraint and that this risk could be significantly reduced through the use of child restraint systems (CRS) [1]. Child restraint systems, including rear- and front-facing five-point restraint car seats and booster seats, are highly effective mechanisms to prevent child passenger injuries [7-9]. CRS, when correctly installed and used, can be very effective with evidence showing that they reduce the need for hospitalization by $69 \%$ in the under 5 age group and the risk of death by approximately $70 \%$ for infants and by $47 \%$ to $54 \%$ for toddlers (aged 1 to 4 years) [10,11]. A child up to 4 years of age has a $50 \%$ lower risk of injury in a forward-facing child restraint and $80 \%$ lower in a rear-facing seat [12]. This compares with injury reductions of only $32 \%$ when an adult seatbelt is worn. For children aged 5-9 years, child restraints reduce injury by $52 \%$, whereas for seat- belts alone the reduction is only $19 \%$. For older children aged 10-14 years seatbelts reduce injury by $46 \%$ [12].

Despite this evidence CRS use rate is low in many countries; for example, the rate of use among children under 5 years of age ranged from $7.9 \%$ to $17.4 \%$ in two Mexican cities [13]. This is similar to the observed child restraint use in Ghana with a proportion of 13.2\% [14]. Even in countries with high use rate, correct and appropriate restraint use can still be a problem [15]. Observational data show that children and young adults are less likely to use seatbelts than adults [16]. According to statistics from the Child Accident Prevention Foundation of South Africa, $84 \%$ of children in vehicles are not restrained and $80 \%$ of children who had been injured in collisions were not restrained [17]. A previous observation study conducted at the main gate of the Red Cross War Memorial Hospital in Cape Town in 2008 showed that only $3 \%$ of observed children were adequately restrained [18].

Comprehensive legislation which includes laws surrounding child restraint use is a critical component in a child road traffic injury prevention effort [1]. The latest World Health Organization Global Status Report on Road Safety indicates that only 33 countries have a child restraint law in place which aligns with best practice [19]. Consequently, improving child restraint usage is one of 12 performance targets recently adopted by the United Nations General Assembly. The South African law on child restraints does not satisfy best practice. The amendment to the road safety law that was introduced in 2014 mandates the use of a South African Bureau of Standards-approved child restraint for all child passengers under the age of 3 years. This does not adhere to the United Nations (UN) prescribed best practice law that requires the use of suitable child restraints for children up to the age of 12 based on age, height and weight [20]. Experience from high-income countries shows that even when a comprehensive legislation exists, high rates of use are not possible without complimentary educational programmes, increased enforcement and supportive programmes to distribute CRS such as loan incentive schemes [10]. Barriers to increased use, particularly in LMICs include the cost of the child restraint, lack of knowledge and awareness of parents and caregivers and relatively low safety standard for vehicles $[15,21,22]$. However, there is little empirical data to support this. To guide the development of interventions and to persuade policy makers to focus on this under-served population, studies are needed that explore these barriers. This study aims to address the current gap in the scientific literature surrounding the barriers to CRS use in a middle-income setting by determining the availability and affordability of certified child restraints amongst different populations in Cape Town. This study was conducted as part of a larger mixed method study of child restraint use in Cape Town and therefore is not exhaustive in terms of data collected and analysis. The findings reported in this article will be combined with a systematic review of child restraint usage, a quantitative analysis of hospital data in Cape Town, qualitative data from focus groups and in-depth interviews of road safety experts in Cape Town and a review of legislation, which will serve to develop a brief intervention that will be evaluated through an appropriate study.

This study was done in collaboration with the George Institute for Global Health UK, University of Oxford, the ChildSafe team at the Red Cross Children's Hospital, the University of Cape Town and the SA Medical Research Council. Ethical approvals were obtained from both the University of Oxford and the University of Cape Town. 


\section{Materials and Methods}

To gain in-depth insight into the barriers surrounding CRS use we utilized both an unobtrusive observational study and a cross sectional survey between September 2019 to November 2019 in Cape Town, South Africa.

\subsection{Study Setting}

Cape Town is the largest city of the Western Cape Province in South Africa and is home to $64 \%$ of the Western Cape's population. It is the second most populous city in South Africa after Johannesburg. Seven suburbs across Cape Town were selected to give a good representation of ethnic groups and socio-economic status. To try and maximize response rates and increase denominators, study sites within these suburbs were purposively selected to include hospital settings and childcare facilities. Hospitals and daycare centers were approached by the research team to request permission to carry out data collection. Table 1 shows the site selection that was used for both observational studies and the survey.

\subsection{Observational Study}

For the observational study, a standardized observation form was developed with the local ChildSafe team. Any vehicle with at least one child occupant age 14 years or under (estimated based on observations) seen to be entering the car park of the study site was eligible for the study. A team of local fieldworkers were recruited based on previous connections and knowledge of ChildSafe work. They were trained using a two-step process that included theoretical and practical knowledge. The theoretical aspect involved "in-classroom" teaching sessions to explain the nature of the study, to familiarize the fieldworkers with the survey forms and study protocols and to help them identify the different types of CRS that are currently available in South Africa. Fieldworkers were also trained on how to estimate the age of children. This was followed by the practical session in the car park of the hospital to give the fieldworkers an opportunity to use the forms and practice estimating ages of children in the front/backs of vehicles. This was used as a pilot test of the form and subsequent modifications were made to make data collection easier and more accurate. Teams of two fieldworkers were allocated specific sites and time slots. Due to the high rates of crime and violence in South Africa, the protection of fieldworkers was paramount. Homicide accounts for $56 \%$ of fatal injuries amongst individuals aged 15-34 years in South Africa $[23,24]$. The safety of fieldworkers was therefore ensured by the local study team with hi-visibility jackets being provided and advice given on safe zones for data collection. Data were collected in time slots of two hours throughout the day from 8am to $5 \mathrm{pm}$ ensuring that drop-off and pick-up times at the childcare facilities was captured. No night-time data collection occurred, again to safeguard the fieldworkers from potentially dangerous situations. Fieldworkers stationed themselves where vehicles were forced to slow down near the entrance/exit barriers to centres. Both fieldworkers were instructed to observe the cars and collect data on each vehicle, verbally verifying with each other the details of CRS usage. Forms were collated at the end of each day and taken to the ChildSafe offices for data cleaning, quality checks and data capturing.

\subsection{Survey}

For the survey, a questionnaire comprising of 30 questions was developed based on previous studies and modified to take local culture and context into consideration by translating into two additional official languages spoken in the city (Afrikaans and Xhosa) together with English. Any driver who was seen to have children was approached to respond to the survey. Asking parents/carers who had lost a child because of a road traffic injury to answer the survey was felt to be too sensitive therefore any respondent who made the fieldworkers aware of such an event was excluded from the study. Similar to the observational study, local fieldworkers were trained in both "in-classroom" sessions and field work piloting. The in-classroom teaching went through each question of the survey and 
interview techniques to try and maximise a positive response rate. The practice session served as a pilot and based on feedback from both interviewers and interviewees, modifications were made to the questionnaire to shorten it and to reword certain questions in South African vernacular and to restructure questions which may have been construed as being too sensitive in nature (e.g., on income level). Teams of two fieldworkers were allocated to the study sites on specific days. These fieldworkers were chosen based on whether their linguistic proficiencies in speaking the local dialect and English. Data forms were collated at the end of each day and taken to ChildSafe for data cleaning, quality checks and capturing.

Quality was assured by the ChildSafe study team for both studies with random spot checks being undertaken.

Descriptive statistics were used to summarize the main findings of the observational data with Fishers Exact test and Chi-squared statistics being used to test the relationship between variables.

\section{Results}

A total of 98 surveys (58.3\%) were captured during the study period, while 70 (41.7\%) of the 168 participants declined. The observational study recorded 279 observations during the study period. Table 1 gives the breakdown of survey responses and total observations by study site.

Table 1. Total number of survey responses and observed vehicles in study sites.

\begin{tabular}{|c|c|c|c|c|c|}
\hline \multirow{2}{*}{ Site. } & \multirow{2}{*}{ Suburb } & \multicolumn{3}{|c|}{ Survey Responses } & \multirow{2}{*}{ Observational Study } \\
\hline & & Yes & No & Total & \\
\hline \multicolumn{6}{|l|}{ Daycares: } \\
\hline Site 1 & Seapoint & 22 & 25 & 47 & 56 \\
\hline Site 2 & Gugulethu & 4 & 3 & 7 & 20 \\
\hline Site 3 & Athlone & 2 & 8 & 10 & 21 \\
\hline \multicolumn{6}{|c|}{ Hospitals: } \\
\hline Site 4 & Khayelitsha & 17 & 9 & 26 & 33 \\
\hline Site 5 & Mitchells Plain & 23 & 15 & 38 & 83 \\
\hline Site 6 & Athlone & 17 & 4 & 21 & 44 \\
\hline Site 7 & Wynberg & 13 & 6 & 19 & 22 \\
\hline TOTAL & & $98(58.3 \%)$ & $70(41.7 \%)$ & 168 & 279 \\
\hline
\end{tabular}

\subsection{Observational Survey Results}

Across the 7 sites, a total of 279 vehicles carrying 373 children age $0-14$ were observed. Just over three quarters of the vehicles carried only one child passenger $(n=211 ; 76 \%$ ), with $18 \%$ carrying two children, and 7\% carrying three or more children. Approximately $16 \%(n=59)$ of observed children were estimated as being less than 1 year old, $41 \%(n=154)$ between the ages of 1 to 3 and $42 \%(n=160)$ were categorised as older than 3 years old. 306 children were observed to be seated in the back seats compared with 67 children in the front seat.

Overall, 326 children were observed to be unrestrained (87.1\% 95\% CI 83.6-90.6\%) with only 29 children $(7.8 \% 95 \%$ CI 5.3-11\%) observed to be restrained in a formal CRS in either the front or back seat and 18 children observed to be wearing seatbelts (5.1\% 95\% CI 3.1-7.8\%). Of those seated in the backseat, the majority $(n=269)$ were unrestrained $(87.9 \% 95 \%$ CI 83.7-91.3\%) whilst only 28 of all children seated in the back seat ( $9 \% 95 \%$ CI 6.2-13\%) were observed in a formal CRS. Eleven of the 67 children who were observed to be seated in the front seat of the car were restrained with just one child using a dedicated child restraint (16.4\% 95\% CI 8.5-27.5\%) (Figure 1). The Pearson chi-square statistics indicate that there was no significant relationship between seating position in the vehicle and child restraint use ( $p$-value 0.527$)$. 


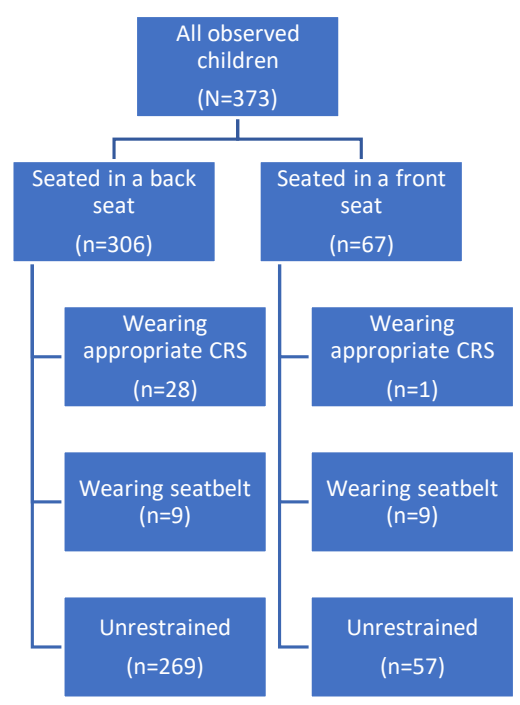

Figure 1. Numbers of children observed to be restrained and unrestrained in the front and back seats.

Table 2 shows the number of restrained and unrestrained child occupants stratified by age and location in the car. For all child occupants, the Fisher's exact test statistics indicated that there was no significant relationship between age and restraint use (either seatbelt or restraint use; $p$-value 0.184 ).

Table 2. Numbers of observed children stratified by age and seating position.

\begin{tabular}{ccccc}
\hline & \multicolumn{3}{c}{ Age } & \multirow{2}{*}{ Total } \\
\cline { 2 - 4 } & $<$ Year & $\mathbf{1 - 3}$ Years & $>$ 3 Years & \\
\hline Front Seat & 3 & 30 & 24 & $57(85.1 \%)$ \\
Unrestrained & 0 & 1 & 0 & $1(1.5 \%)$ \\
Restrained in CRS & 0 & 2 & 7 & $9(13.4 \%)$ \\
Restrained by seatbelt & 3 & 33 & 31 & $67(100 \%)$ \\
Total & & & & \\
Back Seat & 49 & 99 & 121 & $269(87.9 \%)$ \\
Unrestrained & 7 & 21 & 0 & $28(9.2 \%)$ \\
Restrained in CRS & 0 & 1 & 8 & $9(2.9 \%)$ \\
Restrained by seatbelt & 56 & 121 & 129 & $306(100 \%)$ \\
Total & & &
\end{tabular}

Only 92 drivers of the 279 cars observed were seen to be wearing a seatbelt themselves (33\% 95\% CI 27.5-38.8\%). Table 3 shows the relationship between driver seatbelt use and CRS use. Adjusting for multiple children per car with the same driver, the Pearson chi-squared statistic demonstrated that there was a significant relationship between driver's seatbelt usage and use of restraint for child ( $p$-value 0.000). 68 cars that had more than one child per car, the majority of these ( $n=62,91.1 \%$ ) had all child occupants unrestrained with the remaining 6 cars having a mix of unrestrained and restrained children. The Fishers exact statistic indicated a significant relationship between multiple children in one car and use of child restraint ( $p$-value 0.000).

Table 3. Child restraint use compared to driver seatbelt use.

\begin{tabular}{cccc}
\hline & \multicolumn{2}{c}{ Child in Restraint? } & Total \\
\hline Driver Wearing Seatbelt? & $\boldsymbol{n}$ & $\mathbf{Y}$ & \\
\hline$n$ & $250(73 \%)$ & 7 & 257 \\
Y & $94(27 \%)$ & 22 & 116 \\
Total & 344 & 29 & 373 \\
\hline
\end{tabular}

$\mathrm{Chi}^{2} p$-value $=0.000$. 


\subsection{Survey Results}

\subsubsection{Demographics}

Excluding the 24 surveys that were undertaken by the fieldworker who did not adhere to study protocol and was identified by the quality checks, a total of 168 people were approached by fieldworkers to participate in the affordability/availability survey across the 7 sites. Of these, 98 were willing to respond giving an overall response rate of $58 \%$. Table 4 shows the summary demographic data of the survey respondents.

Table 4. Characteristics of Survey Respondent.

\begin{tabular}{|c|c|c|c|}
\hline Characteristic & & $n$ & $\%$ \\
\hline \multirow[t]{6}{*}{ Relationship to the children) in car $(n=98)$} & Mother & 38 & $39 \%$ \\
\hline & Father & 49 & $50 \%$ \\
\hline & Other Relative & 6 & $6 \%$ \\
\hline & Friend of child's parents & 3 & $3 \%$ \\
\hline & Taxi driver/Hired Driver & 2 & $2 \%$ \\
\hline & Other & 0 & $0 \%$ \\
\hline \multirow[t]{2}{*}{ Sex of respondent $(n=78)$} & Male & 47 & $60 \%$ \\
\hline & Female & 31 & $40 \%$ \\
\hline \multirow[t]{5}{*}{ Age of respondent $(n=94)$} & $<30$ years old & 14 & $15 \%$ \\
\hline & 30-39 years old & 42 & $45 \%$ \\
\hline & $40-49$ years old & 30 & $32 \%$ \\
\hline & $50-59$ years old & 6 & $6 \%$ \\
\hline & $\geq 60$ years old & 2 & $2 \%$ \\
\hline \multirow[t]{3}{*}{ Age of child(ren) in car $(n=133)$} & $0-2$ years & 36 & $27 \%$ \\
\hline & $3-8$ years & 83 & $62 \%$ \\
\hline & 9-14 years & 12 & $9 \%$ \\
\hline \multirow[t]{4}{*}{ Highest level of education of respondent $(n=90)$} & No schooling & 1 & $1 \%$ \\
\hline & Primary school & 0 & $0 \%$ \\
\hline & Secondary or high school & 48 & $53 \%$ \\
\hline & $\begin{array}{l}\text { Post school education (such as } \\
\text { college or university) }\end{array}$ & 41 & $46 \%$ \\
\hline \multirow[t]{4}{*}{$\begin{array}{c}\text { Number of years that respondent has been } \\
\text { driving }(n=94)\end{array}$} & $<10$ years & 33 & $35 \%$ \\
\hline & 10-14 years & 37 & $39 \%$ \\
\hline & 15-19 years & 12 & $13 \%$ \\
\hline & $\geq 20$ years & 12 & $13 \%$ \\
\hline \multirow{2}{*}{ Does respondent own the car? $(n=88)$} & Yes & 85 & $97 \%$ \\
\hline & No & 3 & $3 \%$ \\
\hline \multirow[t]{9}{*}{$\begin{array}{l}\text { Total Monthly Family Income in South African } \\
\qquad \text { Rand }^{*}(n=97)\end{array}$} & $<\mathrm{R} 1600$ & 0 & $0 \%$ \\
\hline & R1 600-R3 200 & 1 & $1 \%$ \\
\hline & R3 201-R6 400 & 4 & $4 \%$ \\
\hline & R6 401-R12 800 & 10 & $10 \%$ \\
\hline & R12 801-R25 600 & 16 & $16 \%$ \\
\hline & R25 601-R50,000 & 5 & $5 \%$ \\
\hline & $>\mathrm{R} 50,000$ & 3 & $3 \%$ \\
\hline & I don't know & 20 & $21 \%$ \\
\hline & Do not wish to answer & 38 & $39 \%$ \\
\hline
\end{tabular}

* At the time of manuscript preparation 1USD was equal to R14.83.

\subsubsection{Knowledge of the Current Law}

Ninety-two percent $(n=96)$ of respondents who answered the question about legislation claimed to have some knowledge of the legal requirements for child restraints in South Africa. However, only $32 \%$ of those respondents were able to correctly identify the age requirements stipulated in the law under which a child must be restrained (under 3 years old) (Figure 2). Seventy percent correctly 
identified that the police penalty for breaking the law was to receive a fine whereas $24 \%$ believed that they would only receive a warning. Those that correctly identified a fine as being the penalty received were asked to state the monetary value of the fine (Figure 3). No respondents correctly identified the legal fine of $250 \mathrm{R}$ (17USD). Statistical tests showed a significant relationship between knowledge of law and education level ( $p$-value 0.001 ) and monthly family income ( $p$-value 0.000$)$. There was no statistical difference based on gender, age of driver or years of experience in driving.

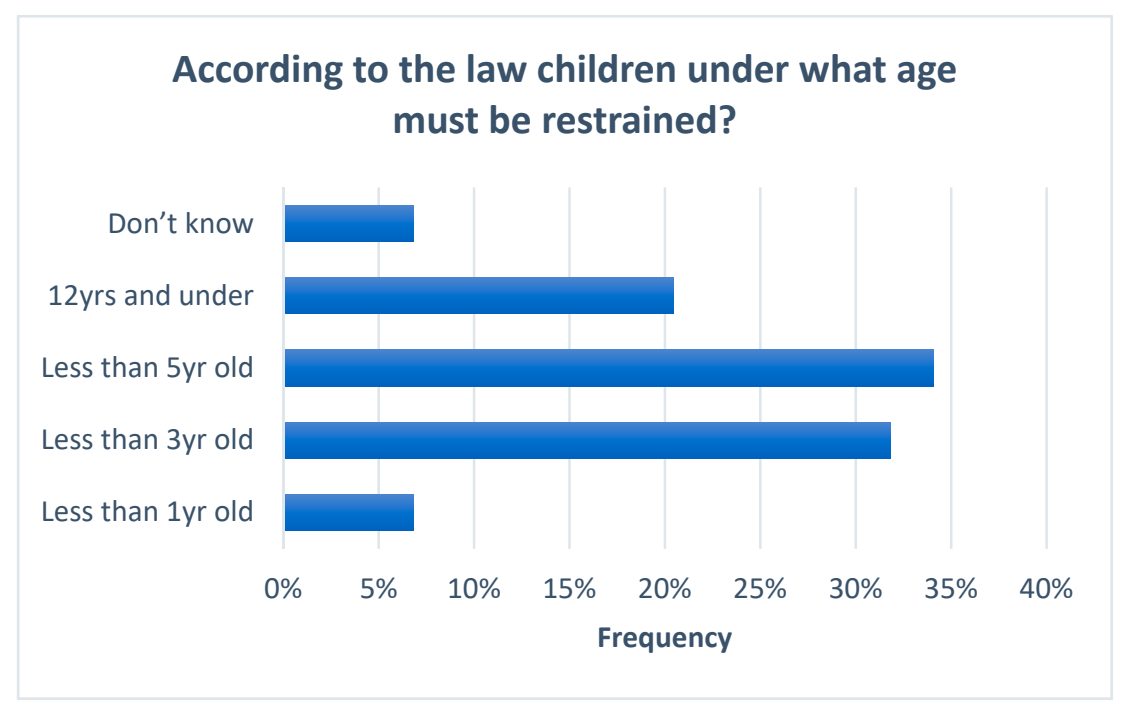

Figure 2. Survey respondent knowledge of current South African law on child restraints. Respondent knowledge of child restraint legislation in South Africa. (NB Correct age according to the law is "Less than 3yrs old").

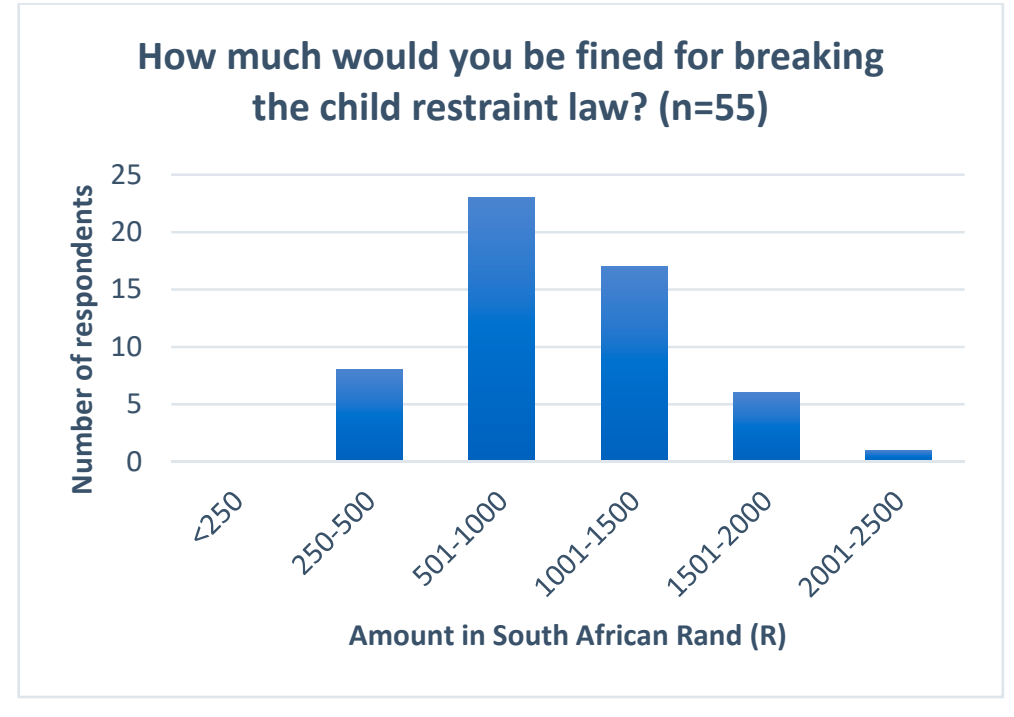

Figure 3. Survey respondent knowledge of fine penalty. Respondent knowledge of fine penalty for breaking the child restraint law. (NB Correct response was $<250$ Rand).

\subsubsection{Importance of Child Restraints}

The overwhelming majority of respondents $(n=92 ; 95 \%)$ stated that they believed it was important to correctly secure a child under 3 years of age in an appropriate child restraint. Of the 5 respondents that believed it was not important, the reasons cited included that they did not feel restraints were effective, that is was safer to have the child sit on an adult's lap, that they were too expensive, it was too difficult to install and that they were an inconvenience to use. Ninety-two percent $(n=82)$ of those 
who did feel it was important stated that it was because it was required by law with $83 \%(n=74)$ stating that they felt it was important as they could be fined by a traffic officer if they did not use one. A further $93 \%(n=83)$ believed it to be safer for the child if they used an appropriate child restraint.

\subsubsection{Child Restraint Ownership}

Of the 93 respondents who answered the question, almost half (49\%) did not own a child restraint. Pearson chi-squared statistics indicated that there was a significant relationship between level of education and CRS ownership and income level and ownership. The reasons given for not owning a child restraint are shown in Figure 4 below with the majority citing costliness and a belief that seatbelts are an adequate alternative.

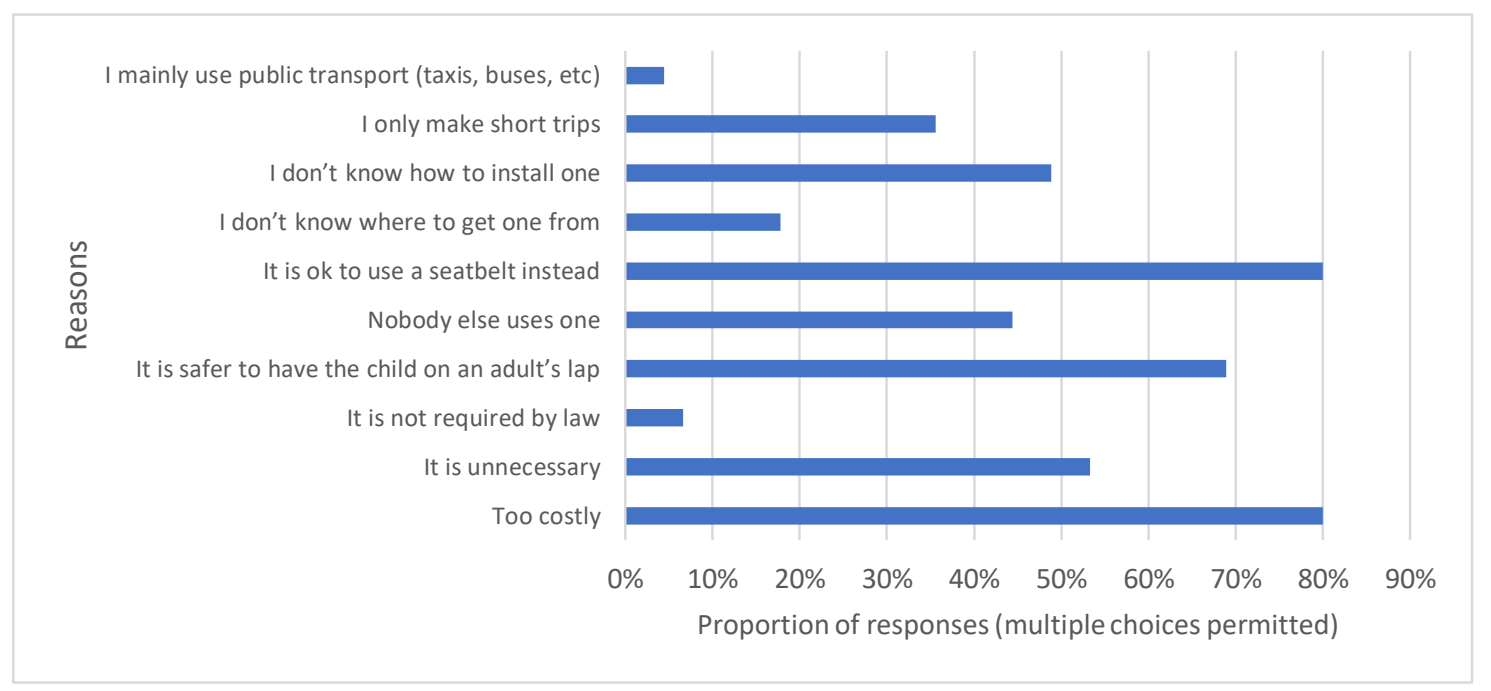

Figure 4. Reasons for not owning a child restraint amongst survey respondents. Reasons for not owning a child restraint system.

Those that did own a child restraint were asked to answer a series of questions regarding their purchase (Table 5). As may be expected, the Pearson chi-squared statistical tests showed a significant relationship between purchasing a new CRS from the store or online and family income level ( $p$-value 0.001). Of those that owned a child restraint $36 \%$ disclosed that they did not always use the child restraint. The most common reasons stated for not using the child restraint were the belief that it was unnecessary for short trips $(n=10)$, the child did not like to sit in the seat $(n=10)$ and that the respondent owned more than one car and didn't have child restraints in all cars $(n=8)$. Four respondents believed it was as safe to have an adult holding the child on their lap.

\subsubsection{Information on and Cost of Child Restraints}

The majority of respondents stated that they would look online for information pertaining to CRS $(88 \%)$ with a further $80 \%$ turning to magazines/books and $78 \%$ seeking advice from family and friends. A third of respondents (33\%) stated that they would not be willing to pay for a child restraint and a further $22 \%$ would be willing to pay up to R500 (33USD). Twenty-four percent would be willing to pay over R1000 for a CRS (67USD). 
Table 5. Factors associated with purchase of child restraint.

\begin{tabular}{llc}
\hline & $n$ & $\%$ \\
\hline Where was car seat purchased? & & \\
Hand me down from relative or previous child & 11 & $23 \%$ \\
Garage sale & 1 & $2 \%$ \\
Bought online & 8 & $17 \%$ \\
New from store & 26 & $54 \%$ \\
Car seat exchange program & 0 & $0 \%$ \\
Gift, Brand new & 2 & $4 \%$ \\
\hline How much did the car seat cost? & & \\
It was free (e.g., a gift or handed down) & 11 & $22 \%$ \\
R1-R999.99 & 7 & $14 \%$ \\
R1000.00-R2999.99 & 27 & $53 \%$ \\
R3000.00-R4999.99 & 3 & $6 \%$ \\
R5000.00-R699.99 & 1 & $2 \%$ \\
R7000.00 and above & 0 & $0 \%$ \\
I Don't know & 2 & $4 \%$ \\
\hline What factors were important when purchasing & & \\
the car seat? & & \\
Colour & 23 & $14 \%$ \\
Price & 19 & $12 \%$ \\
Style/look & 24 & $15 \%$ \\
Quality & 35 & $22 \%$ \\
Brand/company name & 8 & $5 \%$ \\
Easy to install & 23 & $14 \%$ \\
Age appropriate seat & 21 & $13 \%$ \\
Recommended to me by somebody & 8 & $5 \%$ \\
Other (please specify) & 1 & $1 \%$ \\
\hline
\end{tabular}

\section{Discussion}

The observational study showed that, despite the passing of legislation in 2014, CRS use among children remains very low in Cape Town (7.8\%). This is disappointingly lower than previous studies from 2008 and 2019 in South Africa which indicated rates of $11 \%$ and $18 \%$ respectively $[18,25]$. This proportion is significantly lower than some high-income countries where rates of $86-99 \%$ have been reported [26]. However, the prevalence is comparable to other developing countries such as Mexico, Ghana and China [13,14,27-29] where restraint use for children under 5 years of age is less than $4 \%$. This is further supported by the findings from the survey and other studies which suggest that higher education levels and income levels are linked with increased CRS use and ownership [30]

A large proportion of children ( $84 \%$ ) were observed to be sitting in the front seat of the vehicles, unrestrained. It is known that children who are unrestrained or sitting in the front seat face the greatest risk for death in road traffic crashes [31,32]. The relationship between driver seatbelt use and CRS use is well documented in the literature [33,34]. This potentially has implications in terms of opportunities to influence parental/carer seatbelt usage through increased enforcement and targeted education programs surrounding seatbelt legislation in South Africa [35].

In this study there was a significant association between CRS use and driver seatbelt use and multiple children. These findings are found elsewhere in the literature particularly in LMIC such as Nigeria and Brazil [36-38]. This supports the premise that if efforts to increase seatbelt use amongst adults were strengthened, it may lead to increased child restraint use if parents are more sensitized to the importance of seatbelts and restraints and if children, who are known to learn by example and replicate the actions of their parents also engage in the process.

The parent/carer survey indicated that there was a high level of reported knowledge surrounding child restraint legislation in South Africa (92\%), however, when asked to accurately recall the age limits of the law only a small proportion could do so $(32 \%)$. Whilst $74 \%$ of respondents correctly 
identified a fine as being the penalty received for breaking the law, no respondents could recall the precise fine amount with all responses estimating it to be higher than the current legal fine of 250 $\mathrm{R}$ (17 USD). The findings from the survey add strength to the argument that the current legislation in South Africa remains ambiguous as to the correct age that a child should be restrained and the appropriate positioning of the child [20]. It also supports the notion that the current fine remains too low to act as a deterrent to drivers in South Africa driving with unrestrained child passengers [20].

Results from the survey indicate that whilst most parents/carers (95\%) believed that child restraints were important, only $51 \%$ actually owned a car seat and $36 \%$ of those who had one admitted to not always using it. The reported use was higher than in other countries such as Turkey $(20 \%)$ and Kuwait $(26 \%)[39,40]$. The relatively low proportion of parents/carers who admitted to not always using a car seat despite owning one (36\%) demonstrates that although parents/carers are aware of the need to use a restraint, there is a perception that there are certain circumstances where it is acceptable to not use one (e.g., on short trips, if the child does not like it, or if an adult was able to hold a child on their lap). These findings of inconsistent use are highlighted in other studies and suggest the need for targeted education interventions for such populations [41,42]. Utilising platforms such as well baby clinics, maternity wards, early learning centers to increase the general awareness of risks and debunking of certain myths surrounding CRS use would be beneficial. ChildSafe, a campaign run by the Child Accident Prevention Foundation of Southern Africa (CAPFSA) and Safe Kids Worldwide, promotes the use of CRS through organised events, workshops, targeted leaflets/posters and home safety education programs empowering parents/carers of previously injured children to prevent future such incidents. [43]. Studies from other low-income countries have shown that road safety programs which combine policy, enforcement, education and advocacy can be effective in increasing the rate of both seatbelt and child restraint usage. In Lipetskaya, child restraint usage increased from $20.9 \%$ to $51.4 \%$ from baseline to four years after program implementation [44].

Reasons given for not owning a CRS were diverse however the majority of respondents made the argument that the use of a seatbelt was an adequate alternative and reported that the cost of car seat was too high. Of those who did own a car seat, the majority of CRS had been bought new from a store $(54 \%)$ or online $(17 \%)$ suggesting that parents/carers were more willing to pay money for new car seats. The costs of car restraints in South Africa range from R 1000 (67USD) to R 4600 (310USD) which is more than what $55 \%$ of the respondents were willing to pay. As highlighted, there was a relationship between income level and purchasing of a new car seat with those in the lower income brackets being less likely to have purchased a new seat from a store or online. This finding is mirrored in other studies where those in lower socio-economic groups were less willing to pay for car seats [45]. The provision of low-cost/subsidised CRS or borrowing schemes would help to mitigate against lower ownership rates. Organizations such as Wheel Well have been increasing the awareness of parents about the importance of CRS and increasing use through car seat exchange programs which give low-income families the opportunity to receive a second-hand car seat in exchange for an affordable donation [46]. Given the large proportion of respondents stating that they would look online for information regarding their car seats, increasing ownership through targeted social media marketing may prove effective. Other financial motivations may include car insurance programs which provide incentives to parents who buckle up their children in appropriate CRS.

This study has several limitations. Available human, time and financial resources only permitted for a short window for data collection and therefore the sample sizes involved for both the survey and the observations is relatively low. Estimation of the age of children was also a limitation with the observational study. The fieldworkers were given some training in how to estimate such ages however, particularly with seated children being viewed through car windows, these estimates may not have been accurate. Given that the current legislation in South Africa pertained to children under 3 years of age, a decision was made to categorize children into under 3 year old and above 3 years in order to try and minimize such errors. This has implications for data analysis and its generalizability to the wider geographical area. However, this is the first such study in Cape Town which expands the site selection 
from a tertiary children's hospital, which may integrate an element of bias if parents/carers felt the need to carry sick children in their arms, to include several suburbs with a mix of ethnic groups and rural/urban settings.

\section{Conclusions}

Whilst evidence-based strategies to promote seat-belt usage in LMIC have been well researched, the same is not true of child restraint usage. Whilst evidence-based strategies to promote seatbelt usage in LMIC have been well researched, the same is not true of child restraint usage and as such, this study uniquely provides essential information regarding barriers to the use of, and willingness to pay for child restraints amongst underserved populations in South Africa. The findings from this study have implications in other countries in the region and where similar disparities in income exist. It is hoped that the findings from this study and the previous qualitative studies can be used to leverage support for future research focused on implementing appropriate low-cost interventions for child injury prevention, e.g., brief interventions with high-risk mothers and/or an implementation trial of child restraints, in low $=$ income settings. These future programs of research will generate the evidence needed to encourage policymakers to include these activities in municipal and ultimately national policies and plans.

Author Contributions: Conceptualization, P.P and M.M.P.; methodology, P.P.; A.J.; P.M.; M.P.; M.M.P.; software, A.J..; validation, P.P.; A.J. and P.M..; formal analysis, P.P..; writing— original draft preparation, P.P..; writing—review and editing, M.P.; A.J.; M.M.P.; supervision, S.V.A.; P.M.; A.J.; project administration, P.M.; A.J.; funding acquisition, P.P. All authors have read and agreed to the published version of the manuscript.

Funding: This research was funded by an internal seed grant from The George Institute for Global Health, UNSW, Sydney, Australia.

Acknowledgments: We would like to thank the team at ChildSafe for their commitment to and support of road safety research in South Africa.

Conflicts of Interest: The authors declare no conflict of interest. The funders had no role in the design of the study; in the collection, analyses, or interpretation of data; in the writing of the manuscript, or in the decision to publish the results.

\section{References}

1. Peden, M.; Oyegbite, K.; Ozanne-Smith, J.; Hyder, A.A.; Branche, C.; Rahman, A.; Rivara, F.; Bartolomeos, K. World Report on Child Injury Prevention; World Health Organization: Geneva, Switzerland, 2008.

2. Alonge, O.; Hyder, A.A. Reducing the Global Burden of Childhood Unintentional Injuries. Arch. Dis. Child. 2014, 99, 62-69. [CrossRef] [PubMed]

3. Lozano, R.; Naghavi, M.; Foreman, K.; Lim, S.; Shibuya, K.; Aboyans, V.; Abraham, J.; Adair, T.; Aggarwal, R.; Ahn, S.Y.; et al. Global and regional mortality from 235 causes of death for 20 age groups in 1990 and 2010: A systematic analysis for the Global Burden of Disease Study 2010. Lancet 2012, 380, 2095-2128. [CrossRef]

4. Wyk, V.P.-V.; Msemburi, W.; Laubscher, R.; Dorrington, R.E.; Groenewald, P.; Glass, T.; Nojilana, B.; Joubert, J.D.; Matzopoulos, R.; Prinsloo, M.; et al. Mortality trends and differentials in South Africa from 1997 to 2012: Second National Burden of Disease Study. Lancet Glob. Health 2016, 4, e642-e653.

5. Matzopoulos, R.; Prinsloo, M.; Wyk, V.P.-V.; Gwebushe, N.; Mathews, S.; Martin, L.; Laubscher, R.; Abrahams, N.; Msemburi, W.; Lombard, C.; et al. Injury-related mortality in South Africa: A retrospective descriptive study of postmortem investigations. Bull. World Health Organ. 2015, 93, 303-313. [CrossRef] [PubMed]

6. Prinsloo, M. Estimating Injury Mortality in South Africa and Identifying Urban-Rural Differences, in Public Health and Family Medicine. Ph.D. Thesis, University of Cape Town, Cape Town, South Africa, 2019; p. 191.

7. Elliott, M.R.; Kallan, M.J.; Durbin, D.R.; Winston, F.K. Effectiveness of Child Safety Seats vs Seat Belts in Reducing Risk for Death in Children in Passenger Vehicle Crashes. Arch. Pediatr. Adolesc. Med. 2006, 160, 617-621. [CrossRef] [PubMed]

8. Zaloshnja, E.; Miller, T.R.; Hendrie, D. Effectiveness of Child Safety Seats vs Safety Belts for Children Aged 2 to 3 Years. Arch. Pediatr. Adolesc. Med. 2007, 161, 65-68. [CrossRef] [PubMed] 
9. Arbogast, K.; Jermakian, J.S.; Kallan, M.J.; Durbin, D.R. Effectiveness of Belt Positioning Booster Seats: An Updated Assessment. Pediatrics 2009, 124, 1281-1286. [CrossRef] [PubMed]

10. Keay, L.; Brown, J.; Hunter, K.; Ivers, R. Adopting child restraint laws to address child passenger injuries: Experience from high income countries and new initiatives in low and middle income countries. Injury 2015, 46, 933-934. [CrossRef]

11. Zaza, S.; Sleet, D.A.; Thompson, R.S.; Sosin, D.M.; Bolen, J.C. Reviews of evidence regarding interventions to increase use of child safety seats. Am. J. Prev. Med. 2001, 21, 31-47. [CrossRef]

12. Elvik, R.; Vaa, T.; Hoye, A.; Sorensen, M. The Handbook of Road Safety Measures; Elsevier: Amsterdam, The Netherlands, 2004.

13. Pérez-Núñez, R.; Chandran, A.; Híjar, M.; Celis, A.; Carmona-Lozano, M.S.; Lunnen, J.C.; Hyder, A.A. The use of seatbelts and child restraints in three Mexican cities. Int. J. Inj. Control. Saf. Promot. 2013, 20, 385-393. [CrossRef]

14. Ojo, T.K. Seat belt and child restraint use in a developing country metropolitan city. Accid. Anal. Prev. 2018, 113, 325-329. [CrossRef] [PubMed]

15. Hall, A.; Ho, C.; Keay, L.; McCaffery, K.; Hunter, K.; Charlton, J.L.; Hayen, A.; Bilston, L.E.; Brown, J. Barriers to correct child restraint use: A qualitative study of child restraint users and their needs. Saf. Sci. 2018, 109, 186-194. [CrossRef]

16. Van Hoving, D.J.; Sinclair, M.; Wallis, L. Patterns of seatbelt use in different socioeconomic communities in the Cape Town Metropole, South Africa. S. Afr. Med. J. 2013, 103, 628. [CrossRef] [PubMed]

17. Child Accident Prevention Foundation of South Africa. BUCKLE UP 2013; Child Accident Prevention Foundation of South Africa: Cape Town, South Africa, 2013.

18. Kling, J.; Nicholls, T.; Ntambeka, P.; Van As, A. Restraint use for child passengers in South Africa. South Afr. Med. J. 2011, 101, 146. [CrossRef]

19. WHO. Global Status Report on Road Safety 2018; World Health Organization: Geneva, Switzerland, 2018.

20. Janmohammed, A.; Attwood, P.; Mtambeka, P.; Prinsloo, M.; Peden, M. The need for stronger child restraint laws. S. Afr. Med. J. 2019, 109, 12672. [CrossRef]

21. Chen, X.; Yang, J.; Peek-Asa, C.; Li, L. Parents' experience with child safety restraint in China. BMC Public Health 2014, 14, 318. [CrossRef]

22. Keay, L.; Hunter, K.; Brown, J.; Simpson, J.M.; Bilston, L.E.; Elliott, M.; Stevenson, M.; Ivers, R. Evaluation of an Education, Restraint Distribution, and Fitting Program to Promote Correct Use of Age-Appropriate Child Restraints for Children Aged 3 to 5 Years: A Cluster Randomized Trial. Am. J. Public Health 2012, 102, e96-e102. [CrossRef]

23. Otieno, G.; Marinda, E.; Bärnighausen, T.; Tanser, F. High rates of homicide in a rural South African population (2000-2008): Findings from a population-based cohort study. Popul. Health Metrics 2015, 13, 20. [CrossRef]

24. Seedat, M.; Van Niekerk, A.; Jewkes, R.; Suffla, S.; Ratele, K. Violence and injuries in South Africa: Prioritising an agenda for prevention. Lancet 2009, 374, 1011-1022. [CrossRef]

25. Clay, C.; Van As, A.B.; Hunter, K.; Peden, M. Latest results show urgent need to address child restraint use. S. Afr. Med. J. 2019, 109, 12544. [CrossRef]

26. Peden, M.; Scurfield, R.; Sleet, D.; Mohan, D.; Hyder, A.A.; Jarawan, E.; Mathers, C. World Report on Road Traffic Injury Prevention; World Health Organization: Geneva, Switzerland, 2004.

27. Chen, X.; Yang, J.; Peek-Asa, C.; McGehee, D.V.; Li, L. Parents' Knowledge, Attitude, and Use of Child Restraints, Shantou, China. Am. J. Prev. Med. 2014, 46, 85-88. [CrossRef] [PubMed]

28. Mc Ilvenny, S.; Al Mahrouqi, F.; Al Busaidi, T.; Al Nabhani, A.; Al Hikmani, F.; Al Kharousi, Z.; Al Mammari, S.; Al Hoti, A.; Al Shihi, A.; Al Lawati, A.; et al. Rear seat belt use as an indicator of safe road behaviour in a rapidly developing country. J. R. Soc. Promot. Health 2004, 124, 280-283. [CrossRef] [PubMed]

29. Lei, H.; Yang, J.; Liu, X.; Chen, X.; Li, L. Has Child Restraint System Use Increased among Parents of Children in Shantou, China? Int. J. Environ. Res. Public Health 2016, 13, 964. [CrossRef] [PubMed]

30. Simon, M.R.; Korošec, A.; Bilban, M. The influence of parental education and other socio-economic factors on child car seat use. Slov. J. Public Health 2017, 56, 55-64. [CrossRef] [PubMed]

31. Braver, E.R.; Whitfield, R.; Ferguson, S.A. Seating positions and children's risk of dying in motor vehicle crashes. Inj. Prev. 1998, 4, 181-187. [CrossRef]

32. Arbogast, K.; Kallan, M.J.; Durbin, D.R. Front versus Rear Seat Injury Risk for Child Passengers: Evaluation of Newer Model Year Vehicles. Traffic Inj. Prev. 2009, 10, 297-301. [CrossRef] 
33. Rus, D.; Jurchis, F.; Baragan, E.; Chereches, R.; Peek-Asa, C.; Mocean, F. Child safety restraint usage in Romania-An observational study designDiana Rus. Eur. J. Public Health 2015, 25 (Suppl. 3), 209. [CrossRef]

34. Sam, E.F. Don't learn safety by accident: A survey of child safety restraint usage among drivers in Dansoman, Accra. J. Transp. Health 2015, 2, 160-165. [CrossRef]

35. Urie, Y.; Velaga, N.R.; Maji, A. Cross-Sectional Study of Road Accidents and Related Law Enforcement Efficiency for Ten Countries: A Gap Coherence Analysis. Traffic Inj. Prev. 2016, 17, 686-691. [CrossRef]

36. Eby, D.W.; Kostyniuk, L.P. A statewide analysis of child safety seat use and misuse in Michigan. Accid. Anal. Prev. 1999, 31, 555-566. [CrossRef]

37. De Oliveira, S.R.L.; Carvalho, M.D.D.B.; Santana, R.G.; Camargo, G.C.S.; Lüders, L.; Franzin, S. Child safety restraint use among children attending day care centers. Revista de Saúde Pública 2009, 43, 761-767.

38. Sangowawa, A.; Ekanem, S.; Alagh, B.; Ebong, I.; Faseru, B.; Uchendu, O.; Adekunle, B.; Shaahu, V.; Fajola, A. Child seating position and restraint use in the Ibadan Metropolis, South Western Nigeria: Original contribution. Afr. Saf. Promot. 2006, 4, 37-49.

39. Şevketoğlu, E.; Hatipoğlu, S.; Esin, G.; Oztora, S. Knowledge and attitude of Turkish parents regarding car safety seats for children. Ulusal Travma ve Acil Cerrahi Dergisi = Turk. J. Trauma Emerg. Surg. TJTES 2009, 15, 482-486.

40. Raman, S.R.; Landry, M.D.; Ottensmeyer, C.A.; Jacob, S.; Hamdan, E.; Bouhaimed, M. Keeping our children safe in motor vehicles: Knowledge, attitudes and practice among parents in Kuwait regarding child car safety. Int. J. Inj. Control. Saf. Promot. 2013, 20, 358-367. [CrossRef] [PubMed]

41. Zonfrillo, M.R.; Ferguson, R.W.; Walker, L. Reasons for Child Passenger Nonrestraint in Motor Vehicles. Traffic Inj. Prev. 2015, 16 (Suppl. 2), S41-S45. [CrossRef]

42. Tavakoli, Z.; Davoodi, S.R.; Azimmohseni, M. Factors affecting use and nonuse of child safety car seats in Gorgan, Iran. Traffic Inj. Prev. 2019, 20, 661-666. [CrossRef]

43. ChildSafe. ChildSafe: Keep Kids Safe from Harm. Available online: https://www.childsafe.org.za/index.html (accessed on 1 January 2020).

44. Gupta, S.; Paichadze, N.; Gritsenko, E.; Klyavin, V.; Yurasova, E.; Hyder, A.A. Evaluation of the five-year Bloomberg Philanthropies Global Road Safety Program in the Russian Federation. Public Health 2017, 144, S5-S14. [CrossRef]

45. Jarahi, L.; Karbakhsh, M.; Rashidian, A. Parental willingness to pay for child safety seats in Mashad, Iran. BMC Public Health 2011, 11, 281. [CrossRef] [PubMed]

46. Wheel Well. Wheel Well: For Children in Road Safety. 2008. Available online: https://www.wheelwell.org.za (accessed on 1 January 2020). 